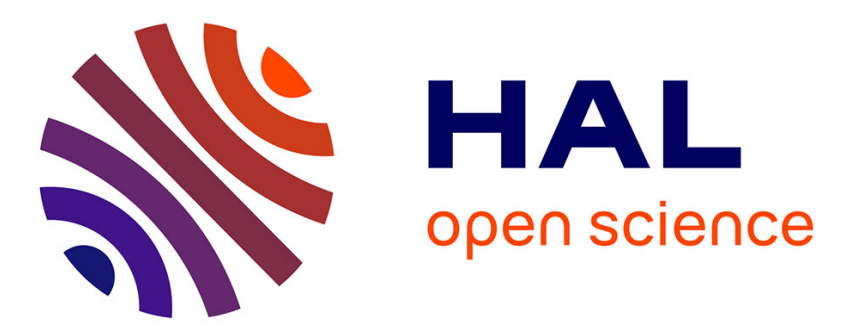

\title{
Analysis of TerraSAR-X data and their sensitivity to soil surface parameters over bare agricultural fields
}

M. Aubert, N. Baghdadi, Mehrez Zribi, C. Loumagne, H. Youssef, P. Ansart, Sébastien Garrigues

\section{- To cite this version:}

M. Aubert, N. Baghdadi, Mehrez Zribi, C. Loumagne, H. Youssef, et al.. Analysis of TerraSAR-X data and their sensitivity to soil surface parameters over bare agricultural fields. ESA-ESRIN Conference EO and Water Cycle science, Nov 2009, Frascati, Italy. p. - p. hal-00473243

\section{HAL Id: hal-00473243 \\ https://hal.science/hal-00473243}

Submitted on 14 Apr 2010

HAL is a multi-disciplinary open access archive for the deposit and dissemination of scientific research documents, whether they are published or not. The documents may come from teaching and research institutions in France or abroad, or from public or private research centers.
L'archive ouverte pluridisciplinaire HAL, est destinée au dépôt et à la diffusion de documents scientifiques de niveau recherche, publiés ou non, émanant des établissements d'enseignement et de recherche français ou étrangers, des laboratoires publics ou privés. 


\title{
Analysis of TerraSAR-X data and their sensitivity to soil surface parameters over bare agricultural fields
}

\author{
Maelle Aubert ${ }^{1}$, Nicolas Baghdadi ${ }^{1}$, Mehrez Zribi ${ }^{2}$, Cécile Loumagne ${ }^{3}$, Youssef Hachouch ${ }^{1}$, Patrcik Ansart $^{3}$, \\ Sébastien Garrigues ${ }^{4}$ \\ ${ }^{1}$ CEMAGREF, UMR TETIS, 500 rue François Breton \\ F-34093 Montpellier, France - maelle.aubert@ teledetection.fr \\ ${ }^{2}$ IRD-CESBIO, 31401 Toulouse, France \\ ${ }^{3}$ CEMAGREF, UR HBAN, Parc de Tourvoie, BP 44, 92163 Antony Cedex, France \\ ${ }^{4}$ CNES DCT/SI/AP, 18 avenue Edouard Belin - 31409 Toulouse Cedex 4, France
}

\begin{abstract}
Due to the complexity of global water cycle and the lack of ground data for modeling systems, remote sensing offer an appropriate tool for the mapping and monitoring of environmental processes. Better understanding and knowledge of soil surface conditions as soil moisture content and roughness are necessary to many environmental applications. These key parameters are of the highest importance in agriculture and vegetation growth monitoring, atmospheric sciences and hydrological studies. Its interest lies in the capability of spatial satellite sensors to provide global and permanent information on the planet, or, on local to regional scales, to provide a spatialized and repetitive vision of territories and ecosystems. Therefore, considerable efforts have been devoted to the use of active microwave remote sensing techniques, in order to measure the superficial soil characteristics of natural surfaces from space. The new Synthetic Aperture Radar systems (e.g. TerraSAR-X, CosmoSky-Med, RADARSAT-2) at high spatial resolution (metre scale) and high temporal periodicity, offer new perspectives for Earth's observation (soil parameters mapping at a fine scale).
\end{abstract}

Our research aims to show the contribution of high resolution spatial sensors (optical and active microwaves) for a better characterization of soil surface, and to analyze polarization effects and radar incidence angle. The objective of this paper is to analyze the sensitivity to surface soil parameters of very high resolution TerraSAR-X radar data taken over bare soils, and to study the spatial variability. The relationship between backscattering coefficient and soil's parameters (moisture, surface roughness, and texture) will be examined by means of satellite images (TerraSAR, Ikonos, SPOT), as well as ground truth measurements, recorded during several field campaigns in the winter and spring of 2008 and 2009. This research will propose multi-sensor approaches (optical and radar) with an aim of better characterizing soil parameters. This study is carried out on Orgeval catchment (France) using images acquired between winter and spring of 2008 and 2009, and in situ measurements recorded during several field campaigns.

Keywords: TerraSAR-X, Ikonos, SPOT, Surface roughness, Soil moisture 